\title{
Forgiveness as a spiritual construct experienced by men serving long-term sentences in Zonderwater, South Africa
}

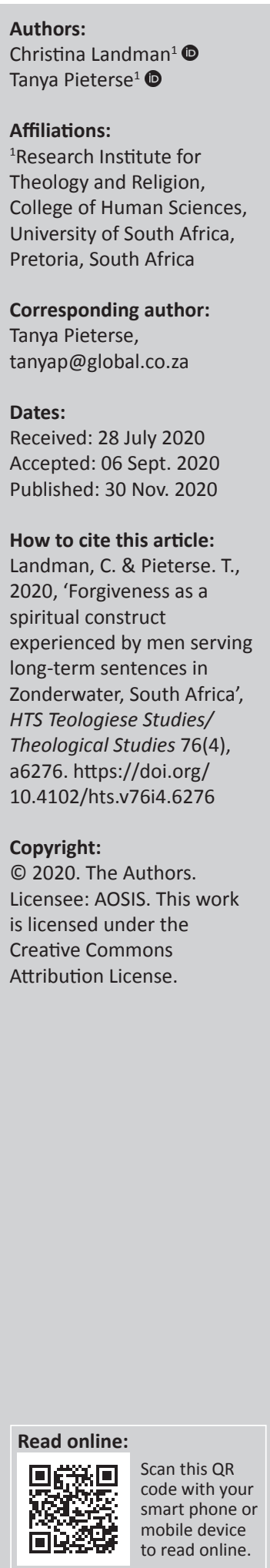

This article presents the findings of research conducted on 'forgiveness' as a spiritual construct, religious survival strategy and meaning-giving tool during incarceration. The research was conducted with 30 men serving long-term sentences in Zonderwater, a correctional centre outside Pretoria, South Africa. A review of literature showed that forgiveness has mainly been seen as something the perpetrator owed the victim and that asking for and granting forgiveness were religious imperatives. However, this study shows that offenders, in the troubled space of incarceration, survived by putting themselves in control of forgiveness. They found peace of mind by granting forgiveness to those who caused them to be incarcerated, whilst at the same time taking responsibility for their own actions. Semi-structured interviews were conducted with the participants. Applying an interpretative phenomenological analysis methodology, the collected data were analysed and the following themes were identified: (1) forgiving those who transgressed against me; (2) the role of politics in forgiveness; (3) God's role in forgiveness; and (4) the effects of forgiveness on the self.

Contribution: This article contributes to an understanding of the construction of forgiveness as experienced by offenders, independent from the traditional victim-offender relations. Living in a troubled, unforgiving space, these men are expected to practice forgiveness by set standards. From their shared narratives, it is illustrated that their spiritual navigation with this phenomenon is not a chronological, time dependent process, but a multidimensional, personal journey to self-discovery.

Keywords: forgiveness; spiritual construct; religion during incarceration; God in troubled spaces, Zonderwater; self-forgiveness; victim-perpetrator; troubled space; interpretative phenomenological analysis.

\section{Introduction}

\section{Aim of the study}

The aim of this article was to report on the findings of a study on 'forgiveness' as constructed by 30 men serving long-term sentences at Zonderwater Management Area, Correctional Centre A (hereinafter referred to as Zonderwater), outside Pretoria, South Africa. Semi-structured, oneon-one interviews, as well as group dialogue sessions on the topic of 'forgiveness', were used to gather information on how the interviewees constructed 'forgiveness'. The participating offenders' experience and understanding of the concept of 'forgiveness' were explored through a lens of the participants' religious and spiritual convictions, as well as other realities that find meaning in their lives.

The concept of 'forgiveness' has been the topic of studies that explore how individuals cope with pain and hurt inflicted by other humans, and especially the people closest to them (Escher 2013:101; Karremans, Van Lange \& Holland 2005:1315). Reports on findings from such studies typically represent a victim-transgressor relationship, with the victim playing a prominent role as the forgiver, and the transgressor being more passive and dependent on the actions or inactions of victims. The focus of this study was independent of any victim-offender relations or acts of forgiveness by the victims. This study aimed to explore the other end of the forgiveness-scope, namely the role of forgiveness in the offender's very personal journey with this concept, that is, in forgiving those who effected his incarceration. This exploration was also mindful of the Note: Special Collection entitled Social Memory Studies, sub-edited by Christina Landman (UNISA) and Sekgothe Mokgoatšana (UL). 
incarcerated space in which the men live and the influence of this troubled space on their navigation with forgiveness.

\section{Background}

The contribution of this study is the unexpected, underemphasised themes uncovered by the researchers that emerged from the shared narratives of these men. This contributes to the body of knowledge in fields such as psychology, theology, sociology and criminology. An outstanding feature of all the discussions with these incarcerated men is that engaging in the practice of forgiveness is not a chronological process within a fixed time frame. It remains a winding road to self-discovery, a process characterised by external forces, as well as an internal calling. Representations shared often displayed the conflict between these forces as acutely experienced by these men.

An important aspect of the participants' practice of forgiveness is the emotional turmoil that forgiving others brings. They struggle with intense feelings of unforgiveness and resentment towards those who caused their incarceration, which adds to an already guilt-ridden life as an offender. They see those who framed them, judged them and abandoned them (such as family and friends) as equally responsible. Those sentiments towards others are, however, not always projected towards persons, but also expressed towards systems that failed and betrayed them such as the justice and political systems, as well as certain ideologies. These issues contribute to what is almost a postponement of their navigation of forgiveness. Added to this is the environment they are confined to. A challenging and often dangerous place, shared with other offenders who are just as troubled, is the cold and unforgiving space they occupy. It becomes a depriving, brutal space that in some cases causes physical, psychological and spiritual hardship (Maguire 2016:32). Within this setting that feelings of distrust, hostility and resentment are rife, where offenders are expected to embrace the concepts and practice of forgiveness as set by the outside world, but in a space far from the norm.

In addition to the aforementioned challenges in these men's journey with forgiveness, they also have feelings of anger towards God. They ask why he allowed wrongful acts to happen, why he forsook them, and where was he when they needed him most. Participants who share these views harbour strong feelings that forgiveness towards God needs to be resolved before significant progress can be made in their journey of forgiveness. These views are experienced as conflicting demands between religious beliefs both from their own convictions and from what others expect, as opposed to the reality of their own intense feelings of abandonment and unforgiveness.

This study also shows how these offenders' navigate the concept of forgiveness, whether desired from, or towards others, is not necessarily a spiritually driven pursuit. To first make amends is not a prerequisite to receiving any godly forgiveness. Seeking forgiveness from others is also not paramount in their forgiveness journey, neither does it regulate their day-to-day incarcerated existence. They voiced a belief that forgiveness will not change anything; it will not change people or systems. Forgiveness, to some, is practised out of purely selfish motives, only to rid one of feelings of guilt. This belief was expressed by the men regardless of their religious affiliations or belief system.

This belief is significantly related to the matter of selfforgiveness, as an internal process and conflicting aspect of their journey as explored in this study. Forgiveness therefore needs to be understood as a dynamic practice and process. The men's shared stories made it possible to identify the vital role of self-forgiveness and showed how resentment towards the self becomes a barrier in the path to granting and receiving forgiveness. This was expressed as an important aspect of how they construct and define their understanding of forgiveness. Self-forgiveness stands in stark contrast with their view of forgiveness as a self-centred act. It is regarded as a vital mechanism for coping with the space in which they have placed themselves, a most unforgiving environment, and the realisation of their own role in causing their incarceration. It is furthermore an essential tool to apply to cope with life whilst incarcerated, to avoid the path of selfdestruction that leads to poor physical, psychological and mental health and spiritual poverty.

The stark reality discovered in this study is the conflicting emotions experienced by the participants in their construction of forgiveness: feeling abandoned in an unforgiving space. The findings of this study that support these conclusions will be presented first by providing a short literature review, secondly by describing the research method and population, followed by a presentation and discussion of the findings and thirdly the conclusion and interpretation. Four themes were identified in the discourses presented by the participants, namely (1) forgiving those who transgressed against me; (2) the political role of forgiveness; (3) God's role in forgiveness; and (4) the effects of forgiveness on the self.

\section{Correlates of forgiveness}

Forgiveness is mainly described as an action of reducing adverse reactions and resentment and replacing it with positive thoughts and responses towards perpetrators and adverse experiences (Escher 2013:102; Peterson et al. 2017:167). Given the daily reports on escalating violent crimes against humans, hate, xenophobia and other ills of today's society, one would expect more research on forgiveness, as a study topic. This, is however, not that common and discussions on this phenomenon revolves much around remembrance of, for example, the Holocaust (Couenhoven 2010:148). Modern discussions by researchers on forgiveness (Couenhoven 2010:166) are limited to having strong religious connotations, as a divine call, or consigned to the spiritual realm (Couenhoven 2010:163; Fincham \& May 2019:1; Miceli \& Castelfranchi 2011:260). The researchers 
of this study found that for most men in this study, forgiveness is experienced in many dimensions, of which only one as a divine calling, to be particularly prominent in their incarcerated lives.

An essential precept in the journey of forgiveness, posing further challenges to the parties involved, is also to understand what it is not. As noted by various theorists, researchers and authors, forgiveness is not to forget, excuse, condone or justify misconduct or, in the context of this study, the criminal actions of offenders, or transgressions against them (Miceli \& Castelfranchi 2011:161; McCullough 2001:194). Forgiveness is not an automatic claim to reconciliation, nor does it mean that all relationships can be restored, but it rather suggests one of the steps in this process (Miceli \& Castelfranchi 2011:161).

The act of forgiving, as suggested by McCullough, Worthington and Rachal (1997:322), is 'not motivation per $\mathrm{se}^{\prime}$, but rather a lay concept that people invoke to describe the transformation from negative thoughts and actions, to being motivated by a more positive, conciliatory approach. This transformation involves a process of change on an 'interpersonal prosocial motivational' level (Karremans et al. 2005:1315). This study focussed on the offenders as persons being affected and feeling wronged, who experience changes on a prosocial level affecting their emotional and behavioural conduct, as well as their thought processes (McCullough, Kurzban \& Tabak 2010:230).

\section{Self-forgiveness}

Attempts to further formulate an understanding of forgiveness, researchers evidently also focus on self-forgiveness, a concept referred to as the 'stepchild of forgiveness research' (Hall \& Fincham 2005:621). Studies on programmes in correctional centres on restorative justice, in the period 2013 to 2015, were conducted in countries such as South Africa, Canada, the United States and Britain. South Africa is among the leading countries in this regard and is often chosen as a source of research (Jacobson \& Fair 2017:2). Results from these studies indicated that one significant challenge for the incarcerated population, one which requires the most exertion in the cycle of forgiveness, is for a person to forgive himself or herself (Jacobson \& Fair 2017:9; Lijo 2018:2), for the transgressions they committed against others (Worthington et al. 2007:293). Self-forgiveness is imperative before relationships can be mended and allows the offender to move forward.

\section{Forgiveness and well-being}

The concept of forgiveness is typically used in correlation with concepts such as revenge and retribution. The need for retribution consumes a person's life and tears at their whole being like a disease. If revenge is a disease, then, as McCullough et al. (2010:222) put it, forgiveness must be the cure. Over time it has been applied as a therapeutic intervention through which depression and anxiety were reduced. Such interventions are, however, not just a simple solution to counter any feelings, or actions of revenge
(McCullough et al. 2010:222). From the 1980s, various studies in the clinical and counselling disciplines have been conducted on the relationship between a person's mental health and forgiveness over their life span (Krause 2018:34; Krause \& Ellison 2003:1; Miceli \& Castelfranchi 2011:269). Further studies by Krause (2018:35) supported these findings and alluded to the view that, globally, for the majority of 'faith traditions' forgiveness is an essential virtue in relation to increased spiritual, mental and physical well-being (Scheffler 2015:6). This in turn shows a positive correlation towards the act of forgiving, encouraging feelings of empathy and self-worth.

\section{Data collection and analysis}

The research data for this study were collected between June 2017 and March 2018. ${ }^{1}$ Semi-structured interviews were conducted with 30 male offenders serving long-term sentences at a correctional facility in Cullinan, a small-town East of Pretoria, named Correctional Centre A, Zonderwater Management Area. The participants were selected by applying purposive sampling, in which a particular population is targeted, with set criteria for the sampling (Terre Blanche, Durrheim \& Painter 2012:139). The criteria for possible participants included: (1) adult male offenders at Zonderwater; (2) those who are serving long-term sentences of more than 15 years; and (3) who, through their lived experiences and spiritual journeys as offenders, transformed into a changed person (Landman \& Pieterse 2019:2).

With the assistance of the in-house psychologist and social worker, a group of 30 men was selected comprising 15 black Africans, 13 whites and 2 of mixed-race descent. The participants were affiliated to a variety of religious or spiritual belief systems, some belonging to more than one tradition. In summary, eight men belong to traditional Christian affiliations, six to traditions that place a strong emphasis on the Torah, four to the Zion Christian Church (a large African Independent Church) and seven men were affiliated to churches that had been established by offenders themselves at Zonderwater. Two men were Muslim and two regarded themselves as atheists, whilst another was associated with Brahmanism (a form of Hinduism), but preferred not to be confined to any specific religious affiliation. With regard to the age distribution of the sample, one offender is in his 20s, one in his 60s, while 11 are in their 30 s and 13 in their 40 s. Four men are in their 50 s. $^{2}$

Ethical clearance was granted by the ethical committees of the University of South Africa and the Department of Correctional Services. Before interviews commenced, each participant was briefed on the aim, method and process to be followed during the research project. The participating men were informed of the ethical principles described by Terre Blanche et al. (2012:67-68) for ethical research, including such

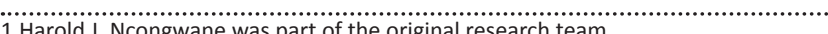
al research team.

2.The authors have previously published two articles based on research with the same research population (Landman, Ncongwane \& Pieterse 2019; Landman \& Pieterse 2019). 
matters as the confidentiality of any information shared, anonymity and their right to withdraw from the study at any stage. Other matters discussed included respect for the dignity of participants, non-maleficence, beneficence and justice. Participants were to be aware that that this study was solely for research purposes and that it had no bearing on their sentences or any parole procedures. All participants agreed to the conditions and gave their written consent.

The semi-structured interviews were guided by a schedule to allow for some structure and to ensure that all the topics aimed to be studied would be covered. Because this only served as a guide, the researchers allowed for the natural flow of conversation and sharing of the lived experiences by the participating offenders.

The data gathered during this study were analysed by using an interpretative phenomenological analysis (IPA) approach. This method allowed researchers to explore the participants' lived experiences and the role of forgiveness in their journey during incarceration (Alase 2017:11). Applying the IPA approach proved ideal in engaging with the participants on forgiveness, as various interpretations of the concept emerged (Alase 2017:11). During this study, researchers and participant journeyed together, and in this dual relationship the researchers shared in their stories, observed and listened to how they make sense of, and constructed the concept 'forgiveness' (Pietkiewicz \& Smith 2014:8) and the role forgiveness plays in the context of their daily lived experiences. This duality in turn allowed the researchers to make sense of their own experiences and engagement with this phenomenon and assisted in understanding and interpreting these offenders' shared stories (Pieterse 2019:62).

Through this dialogue, rich data were collected and significant themes identified. This engagement also allowed participants and researchers to discover their own truths and meanings of forgiveness. The significance of this is that new insights emerged, and the offenders could ask additional questions of themselves and others, in the process of making sense, without the presumption of a right or wrong (Gadamer 2004:361).

\section{Themes uncovered}

In exploring the discourse shared by participants on forgiveness and in analysing it, the researchers found that, whilst incarcerated, every participant is in a different space and time in their journey with forgiveness. Valuable insights were gained during the one-on-one interviews with the participating offenders, as well as during discussion groups. Expressions by the men challenged the researchers' views and opinions on forgiveness concerning what it is, and how it is experienced and practised by the participating offenders. Through our extended journey with this group, we soon discovered that forgiveness as word, process and concept is laden with more than what is generally understood, or what is found in literature searches or textbooks. The sensitivity and knowledge we brought in terms of research skills and the population studied, however, contributed significantly to the exploration of the phenomenon of forgiveness we set out to study.

In the context of the incarcerated, literature defines forgiveness as a one-dimensional process where an offender seeks forgiveness from those he offended. This tendency is, however, not the most urgent need for all, and in our study, the men acknowledged that it is a process dependent on many variables, role players and most of all time (Rowan 2018:302). Although all desire to be forgiven by those whom they have wronged, including victims, family and friends, this was not the focus of this study. An aspect considered in our interpretation of the themes identified is that the incarcerated population is often characterised as having an already tainted background, where the nature of unforgiving, resentment and anger forms part of their reality (Rowan 2018:297).

As Krause and Ellison (2003:2) explain, a person's search for and experience of forgiveness is revealed in different dimensions, and from different sources. Individuals' beliefs and practices of, and experience of, God's forgiveness also differ. The different sources of understanding, or acts of forgiveness, as mentioned, were also found to be true in this study, as voiced by the participating men. Their views and feelings helped the researchers to identify four themes that will form the focus of this discussion, namely (1) a journey in forgiving those who caused the incarceration and suffering; (2) political role in forgiveness; (3) God's role in forgiveness; and (4) effects of forgiveness on the self.

\section{First theme: A journey in forgiving those who caused my incarceration and suffering}

Studies on forgiveness, in most cases, focus on the processes and positive outcomes of forgiving others, typically afforded by a victim to a transgressor (Krause \& Ellison 2003:3). Embarking on this study with the offender as the focus and their personal navigation with the concept of forgiveness are not typical. Offenders are known to have wronged others and should be the ones who seek forgiveness and therefore might seem an unlikely sample in the traditional sense of this phenomenon. Forgiveness is perceived as an almost alien concept to them (Rowan 2018:294) because revenge is their preferred and only means known to deal with those that transgressed against them.

To gain insight into their lives, it is therefore important to explore how they construct meaning of this concept:

'I cannot forgive people who have forced me to do crimes. They must take the responsibility for my crime.' (P4)

The space the offenders are now confined in, however, plays an imperative role in their journey with forgiveness, impacts them at an emotional and cognitive level and escalates the feelings of unforgiveness towards others:

'I have seen the effect of prison on guys ... they crack.' (P22)

'When they locked me up, I swore I will burn this evil place down ... I get how men set themselves alight in prison.' (P10) 
Findings by Krause and Ellison (2003:3) emphasise reports by researchers on the importance of the act of forgiveness of others by the offender. Unresolved forgiveness of those who have wronged them causes feelings of resentment, emotions stronger than the guilt, shame and remorse they experience towards God (Krause \& Ellison 2003:4). Participants echoed this by expressing the strong feelings they experience towards others that wronged them and whom they perceive are the cause of their incarceration and suffering:

'There are people that I have to forgive ... it's difficult you know. Even my co-accused, I must forgive them because we had something, we had to reveal about our case.' (P21)

'I had issues with her about my raising and you know other aspects of life, favouritism, other kids being favoured and my siblings being favoured over me at home ... maybe that played a role.' (P7)

For some men, during their incarceration, it has become a religious or spiritual imperative to forgive others. A road by which they came to realise that even though godly forgiveness and forgiveness of, and between people fundamentally differ, it is not opposing poles, but more of an interactional relationship of one being dependent on the other (Couenhoven 2010:167). It is also a step they could only take by believing that in receiving God's forgiveness they are able, or more commanded, to forgive others (Couenhoven 2010:167; Escher 2013:103; Krause \& Ellison 2003:10), and it almost becomes their testimony:

'I live according to the Word. Because I cannot serve God or have peace if I got someone that I haven't forgiven.' (P25)

'There is power in forgiveness. My religion teaches me that we must forgive, to forgive is not a request, it is a command from God.' (P21)

'It is Christian to forgive people. To treat people as they treat you is satanist.' (P1)

Seeking forgiveness from God is based on a religious foundation, involving various emotional processes. Forgiveness of others is characterised more by the translation of those convictions into positive acts and attitudes towards others and the effect on their lives whilst incarcerated (Krause \& Ellison 2003:4). Those for whom forgiveness forms part of their inherent nature or conviction are also more inclined towards forgiving others (Escher 2013:109). They regard their incarceration as part of God's plan (Rowan 2018:297) and embrace their value and role in this constructive process:

'God has a plan for my life. I forgive people because they are part of that plan.' (P18)

'That's why now I think sometimes God has got a plan because He can see there is this person ... maybe I must take him and put him somewhere maybe he will focus.' (P25)

'I think God did have a plan for me though ... although I did not want to agree to his plan at the beginning.' (P6)

In the researchers' co-journeying with the offenders' in their search for forgiveness, it became evident how many succeed in internalising this process. It has become a practice that greatly contributes to their way of coping (Escher 2013:103). This is also indicative of a relationship with God entwined with these men's journey, believing that if God can forgive them and others, so can they:

'I have forgiven all those who wronged me whilst I was outside.' (P6)

'What I can tell you that I have forgiven everyone, even some of my friends, even some of my family that God revealed their true colours to me, I've already forgiven them.' (P16)

'Honestly ... I prayed for those people, even those people that they arrest us and ... some giving a false statement and so on, I prayed for those people.' (P25)

\section{Second theme: The role of politics in forgiveness}

Individuals form affiliations with various organisations, systems and groups and invest in their policies and beliefs. Such shared values can include matters of a religious, political or social nature (Worthington et al. 2019:10). In South Africa, the past three decades were characterised by many changes in this regard, giving citizens renewed hope and something in which they placed their trust. These changes, mainly in the political arena, affected the country on a constitutional, judicial, economic and societal level (Inazu 2009:318-319). A new 'national narrative' and 'moral order' have been established (Kubai 2016:1), with the majority of South Africans, particularly those previously disadvantaged, hoping to reap the benefits soon after 1994.

Changes and consequent expectations, however, do not come without challenges. This is the reality faced by many citizens, including the participating offender population in this study.

Feelings of resentment were evident in the articulation of their unforgiveness towards systems that failed them and caused their incarceration:

'It was a work-related problem, it was a racial related incident and more politically motivated ... I had to defend myself ... me or them.' (P16)

'Society is the reason I am here. They made me into this. So, who are in the wrong?' (P15)

Religion is one factor in the formation of a person's identity and belief system. In some cases, crucial in the 'legitimising (or de-legitimising)' of a country's political order (Kubai 2016:2), political transformation can, therefore, bring about a shift in multiple ideological practices that affect individuals and groups in different ways. In times of change, people place their fears, trust and hope in their God (Worthington et al. 2019:10). Emerging from the shared narratives of the participants, on various sides of the new and old order spectrum, is how their hopes turned into disappointment, trust into distrust, and how the fear instilled in them was misguided:

'So, I applied for posts internally, but I was not recommended and from that time I was filled up with anger and started to do robbery and so on.' (P29) 
As their religious or belief system frames the meaning of their lives and experiences (Kubai 2016:2), it affects the way they view the transgressions committed against them. Anger, uncertainty and unrealistic expectations resulted in political resentment that left some men disillusioned:

'As a very young man I was influenced by elders of an organisation, who used the Bible to do Wrong, and that still angers me, that I couldn't stand up against their system that caused this.' (P4)

'The justice system failed me ... it took very long and from 22 witnesses, from SAPS, paramedics and so on only two were used. And the state turned against me and put me here [translated].' (P28)

Apart from an altered forgiveness relationship either with their God or divine entity and others, these incarcerated men also have to cope with the feelings of resentment against a system such as the justice, political or an ideological system. These events consequently influence how they perceive forgiveness and how it shapes their lives and thoughts:

'Will forgiveness change anything?' (P15)

'Forgiveness makes you weak.' (P16)

To engage in a practice of forgiveness, expressed by the participants, is an emotional, thought-provoking cycle that continues over years. It is a reflective journey of questioning and begging, of pardoning and acceptance. But maybe most of all, it is a personal process of conscious choices, a spiritual and psychological journey to healing and coping.

\section{Third theme: God's role in forgiveness}

The act and concept of forgiveness is typically referred to as a spiritual or religious relationship a person forms with a higher divinity. A holy connectedness is formed that enhances trust and a significant attachment to God or another superior being or entity (Krause 2018:38; McElroy et al. 2016:191). God's role in the cycle of forgiveness is multi-faceted, as transpired during discussions with the incarcerated men. Such matters, among others, are having a personal relationship with God, seeing God as the reason for his incarceration, seeing God as a role model of grace and love and seeing how incarceration is part of God's plan.

For many followers of the traditional monotheistic religions, repentance before God and to pray for forgiveness forms one of the most important aspects of their belief system. Receiving God's forgiveness is unconditional (Krause \& Ellison 2003:4; McCullough \& Van Oyen-Witvliet 2002:460), as voiced by some participants:

'I believe in the forgiveness of sins.' (P27)

'Guilt is simple, confess your sins and ask God to forgive you.' (P17)

'God gives more grace than punishment.' (P2)

Forgiveness by God is multi-dimensional in nature in that it comprises different forms, to be relieved from guilt, to right one's wrongs and receive God's grace (Edwards 2010:252). Participants expressed their experience of how God saved and freed them from further misery:

'That's why I said it's easy to pray to God to ask God to give us things and to forgive us.' (P25)

'God is the Redeemer.' (P9)

'There is mercy. There is grace. There is forgiveness.' (P20)

A recurring narrative expressed by many participants in this study is, however, the turmoil to forgive God. These men's individual pilgrimage of repentance, seeking or granting forgiveness is evident of a complicated relationship with God, characterised by feelings of anger towards him, as they express:

'Look my first problem ... well it was, where was God that day?' (P10)

'God has made a mess of me. Why should I forgive Him?' (P8)

Many offenders in this study struggle to come to terms with why God did not protect them from committing wrongful acts, why did he allow it to happen, and harbour feelings of unforgiveness towards him:

'God's also in control of bad things, just as he is in control of good things ... you know what I'm saying ... so who put me here?' (P15)

Evident from the foregoing narratives is that the Godforgiveness relationship is not as clear and systematic as one might expect. It is a winding journey from resenting God to a struggle to plead to God, or some other entity, for forgiveness (Magezi \& Magezi 2017:7):

'Everything that went wrong in my life ... even as unlikely as it might sound, even the reason why I am here today has got directly to do with that ... with God's mistake with me ... why I am in prison today.' (P8)

Some of the stories shared by the participants show that this appeal, learning and accepting forgiveness from a divine entity is a toilsome and soul-searching endeavour (Rowan 2018:297), articulated as follows:

'I lost everything, my wife, my kids ... everything. My dignity. I sit here and say to the Lord, Why did You do this? Everyone abandoned me. Sometimes I don't even have clothes or toiletries.' (P20)

The participants further told how their search for forgiveness and for meaning in their lives is impacted by the realities of the environment they are placed in and becomes a continuous struggle to reconcile it with their spiritual journey with God or divine entity:

'Who must I ask for forgiveness or prove myself to? Most days I ask myself what am I doing here? Most days I even struggle to pray. This is not a place you can say halleluja I am forgiven. No. Not with all the crap I am exposed to around every corner [translated].' (P28) 
'How do you keep faith in a God-forsaken place? Twenty-four hours a day, three hundred and sixty-five and a quarter days a year, there is evil everywhere in this place.' (P17)

During their search and struggle with their anger towards God and what his grace entails (Pettigrove 2012:540) the participants formulated their understanding of what God expects in this regard:

'This is very challenging. Even though I pray to God to give Him an understanding that it is not all about me, it is not all about what I did. It's all about what God needs to do to me. Even though it is a very difficult situation, it's all about God.' (P26)

'So sometimes when we don't want to forgive it means that we are disobeying God.' (P21)

'Because if you forgive and He will also be able to forgive us, so we have to learn to obey God.' (P21)

Individuals' unyielding trust in God receiving his forgiveness, however, remains part of these men's spiritual journey and has particular meaning for offenders and how they experience it (Pettigrove 2012:525). As was evident from the participants' conscious engagement with the religious teachings of their respective belief systems and how they construct forgiveness, as well as the reciprocal act thereof:

'Forgive me ... God must forgive me for that.' (P20)

'You have to forgive. If you don't forgive, how can you expect God to forgive you.' (P17)

'I believe that God has forgiven me, and I apologised to those I hurt.' (P5)

Upon reflection, many of these men's navigation with forgiveness during their incarceration involve not only the need to be assured of God's forgiveness, but also to accept his forgiveness (Pettigrove 2012:529):

'It took me long ... to accept God forgives me and accepts me for who I am.' (P12)

In return they learn to accept the sentences imposed upon them by a worldly judge and understand that the offences they committed will not merely disappear. They therefore need God's reassurance of His unconditional love, and ask for a so-called 'loving judgment' (Pettigrove 2012:525) as reiterated by some participants:

'The judge pushed me into the arms of God. I have lost my pride. I forgive.' (P19)

'God is a healer. He is selfless and forgiving.' (P7)

A further belief in the practice of forgiveness by God is that it brings almost total deliverance and liberation, a particularly strong construction voiced by the incarcerated men who were part of this study (Scheffler 2015:2). Thereby, one's past transgressions should not follow you all your life (Pettigrove 2012:525), as echoed by the following:

'There's a feeling of God's forgiveness to me, like it should be a complete process ... taking away accountability also. That's the way God forgives us.' (P8)
The researchers acknowledge that the various representations made by participants are evident that as an incarcerated population, these men put much thought into their construction of forgiveness and its various dimensions. It is found to be more than envisaged, especially that forgiveness from others and God is not necessarily paramount in their reality of searching for meaning, but as the discussion below will explain, forgiveness of others and of the self plays a prominent role.

\section{Fourth theme: The effects of forgiveness on the self}

The act of forgiving oneself, sometimes referred to as selfforgiveness, may be one of the most challenging steps in the forgiveness cycle. It is applied to those in the offender population who struggle with various emotions of guilt or remorse, for the pain inflicted on others (Worthington et al. 2007:293), their family and themselves:

'Am still struggling with forgiving myself for what I have done, especially to my family.' (P6)

During interaction with over 300 offenders, part of the Kairos programme in the USA, Rowan (2018:298) reported that this process requires 'mental gymnastics' by offenders because they have dual roles as transgressor, and the one that needs to forgive others, as well as to forgive themselves. What made this step in the forgiveness cycle challenging for the participating men is that painful memories are recalled that remind them of their transgressions and the hurt caused:

'I couldn't forgive myself, I was blaming myself that I am the cause of this whole problem. Coming to prison, everything I did. Even when they visited me all the family they were crying, I was crying also. I saw the pain that I caused to them. So, I was blaming myself for all these things, so I had to forgive myself first.' (P21)

Self-forgiveness is a painstaking process that can stifle the process of seeking forgiveness from others, from the Divine, or granting forgiveness to others (Rowan 2018:297). A person's journey to self-forgiveness is not forgetting or condoning the transgressions committed, but involves the restoration of the 'moral injury' committed towards oneself (Couenhoven 2010:168) as echoed by the men in this study:

'I forgive myself also. In 2011 when I got sentenced, I could not forgive myself.' (P21)

'At first I struggled to forgive myself here. But I talked a lot to God. God is a God of love. Now I have accepted what I have done. I have accepted who I am.' (P6)

This injury to the self is exacerbated by the unforgiving space in which they spend their days. In most cases this is because of their own actions, which adds to the turmoil they experience in their process of self-forgiveness:

'Some days when you wake up you ask where am I ... after years it is still unreal ... why am I here so long in this horrible place? I feel that I have done what I could to change, I don't know what 
more ... now it's just the time that must pass ... and there's still quite a bit of time left ... what will this place do to me?' (P2)

On the issue of self-forgiveness, through the researchers' interaction with the men an observation that emerged is the reciprocal manner in which the process takes place. Their spiritual journey, as demonstrated in this study, is not an isolated process (Krause 2018:46), but an interactional engagement between God and the self:

'I have already forgiven all those people. Like I said, first I forgive myself. I can't blame you before I blame myself, I have to see things through myself before I can blame you, do you understand?' (P24)

Participants told of the relationship between forgiveness by God and forgiving oneself, and what it means, and how it helped them to cope in their lives whilst being incarcerated, and in their spiritual self-discovery:

'I have forgiven myself. Now the Holy Spirit is using me to change Zonderwater into a Christian Centre.' (P5)

Self-forgiveness becomes important in facing one's transgressions, dealing with them, taking responsibility and choosing to move forward in a constructive manner (Peterson et al. 2017:159):

'I forgive myself for what happened in the past, but if you really understand forgiveness from the heart, you will not commit an offence of the same nature in future and justify it, that would be wrong.' (P27)

Reporting on the findings of this study would not, however, be complete without mentioning some other opinions voiced by the participants. The religious or spiritual claims made are not necessarily supported by all. The interdependent nature of the forgiveness process is also not an essential aspect of this cycle, as some participants strongly believe that:

'Only self to forgive and ask, show me Lord.' (P5)

'You need to only self-redeem. If they forgive me it's their thing, maybe according to their religion.' (P4)

Scheffler (2015:2) explains that, in a religious sense, forgiveness concerns a relief from one's transgressions. The views quoted above, however, represent the feelings of many of the men about how their quest for forgiveness relieves them in a sense from any debt towards others that they might be held accountable. Different expressions shared by the participants demonstrate this notion of Scheffler (2015:2). In voicing their unique experiences of, or convictions about forgiveness, they illuminate various dimensions of their reality:

'I just felt it in my case I don't have to ask for forgiveness ... , but not important because I'm paying the price for what I did.' (P8)

Some religious belief systems, however, regard selfforgiveness as unacceptable, because they believe only God can forgive and release you from your transgressions (Couenhoven 2010:162; Peterson et al. 2017:166), as some expressed:
'Also only know that forgiveness is ... by only God. No other.' (P3)

During the researchers' engagement with the offenders, an honesty was observed in the self reflections of the men's shared lived experiences. An essential feature required in the dynamic process of forgiveness, though maybe not similarly expressed, was voiced by the following:

'Forgiveness is a self-centred thing, you do it for yourself.' (P4)

'You don't have to forgive. You forgive when you think it is the right thing to do.' (P3)

'What will be, has to be. We are not in control of our lives. Will forgiveness change anything?' (P15)

The practice of forgiveness is also therapeutic in nature (Rowan 2018:300) because it requires an awareness of the situation they are in and acknowledging responsibility, not only for the transgression they committed, but also for the need to consciously change from past behaviours (Rowan 2018:300), a notion reiterated by participants:

'As long as you don't forgive you are basically returning to the same poisonous, venomous situation day after day.' (P8)

As a researcher one was acutely aware that there is no one method by which individuals deal with this. Through the men's representations of their journey with forgiveness, it was evident that their emotions fluctuated from anger and regret to solace and peace. Such fluctuating emotions can have a negative effect on a person's psychological well-being and process of healing (Rye et al. 2000:17). The doubt and anguish experienced by these men, the longing for God's forgiveness, by others, towards others and the self was palpable:

'Now I am asking for forgiveness, but people don't want to forgive me. I am inviting Him in, but where is He now?' (P10)

'It took me ten years to forgive the people who have betrayed me.' (P14)

It is important to note that self-forgiveness encompasses different psychological mechanisms than the other forms of forgiveness and is particularly relevant to offenders. They render feelings of guilt and 'self-condemnation' (Worthington et al. 2007:293), and this requires strong mental agility (Rowan 2018:298) to cope with the added psychological distress and pain. As articulated by the participants:

'I think it's because of regrets, unforgiveness, all those things. You know they pile up, they pile up, they pile up, they pile up. So, I don't know eventually if I will be able to come pure again whilst I'm here in prison.' (P15)

'My self-image was destroyed by guilt.' (P12)

One aspect of the process of forgiveness is that it provides some reflection on the self, past and future (Rowan 2018:302). Participants particularly highlighted their awareness of this, and how it helped them to avoid falling into the same 
patterns and thus cause them to self-sabotage (Peterson et al. 2017:167):

'In all this God helps me to be patient.' (P17)

'Jesus said I must go and make things right. It is a command to forgive. It sets me free.' (P24)

The choice a person makes into his own well-being and avoiding any self-destructive behaviour is a conscious one, and most relevant to the environment these offenders find themselves in daily:

'For me it is not [just] about forgiveness, but about associating myself with positive mindset people.' (P23)

'Because for me when I forgive you ... sometimes I can forgive and then we carry on with life like normal, but there are some people that I forgive but draw the line. So, for me not to experience the very same trauma, I'd rather stay away from you and you stay away from me.' (P16)

A significant outcome of this research is participants' conscious engagement with the different forms of forgiveness, and sharing the role it plays in their lived experiences during incarceration:

'Forgiveness helps me to live a life of hope.' (P9)

'I am humble. I am wise. I am forgiven. I forgive.' (P21)

Navigating through the dynamic process of forgiveness and experiencing its positive effects, as described by the participating offenders, are believed to contribute to their finding meaning in life even during times of suffering. They show positive behavioural change and enhanced mental health and well-being (Krause 2018:39; McCullough \& Van Oyen-Witvliet 2002:451).

\section{Conclusion}

This article reported on how 30 men serving long-term sentences construct 'forgiveness' as a spiritual journey and religious survival strategy. Following an interpretive phenomenological approach, interviewers and participants partnered in a dual relationship whilst exploring the offenders' navigation during their forgiveness journey (Pietkiewicz \& Smith 2014:8). This approach requires the researchers to acknowledge their understanding and opinions of, as well as regard, their own experiences in, and reality towards this phenomenon (Scotland 2012:9). Furthermore, the participants as an improbable sample, and within the space they find themselves in, pose another dimension to the reality to be cognisant of.

The value of an interpretive approach lies in the culmination of researcher and participant's lived experiences in their journey with forgiveness. In this regard, whilst interacting with the offenders and their search of how they make sense of their lives during incarceration, the researchers, in turn, are also engaged in their own sense-making process. From our interactions we realised that forgiveness is not a textbook process with fixed steps, a defined right or wrong or a clear beginning and end. During this engagement the four themes that emerged can be summarised as follows:

\section{Forgiveness is shaped by one's lived experiences}

For most offenders, in this study, their concept of forgiveness is characterised by lived experiences of unforgiveness and resentment from previous volatile lives lived. A strong notion expressed by the offenders was feelings of unforgiveness towards people, or systems that caused their incarceration, feelings that often dominate their thoughts and fluctuate between resentment to contentment. It becomes an internal conflicting endeavour where closure seems impossible, because the different role players are absent and unaware of these feelings harboured towards them. It also involves anger towards abstract systems and ideologies. The hostile space they find themselves further escalates this already challenging endeavour. Participants, however, expressed that they believe it is important to let go of feelings of unforgiveness, for their own well-being, and ability to move forward in their spiritual journey. These views highlighted that the act of forgiveness is not necessarily practised from a religious conviction, but is often a personal choice. Regardless of one's religious affiliation or belief system, participants voiced that such a choice ranged from the need to feel better about oneself, to relieve one of any guilt and to selfishly portray a positive image.

\section{Forgiveness in action is not dependent on others' forgiveness}

The practice of forgiveness entails various actions and dynamic relationships. Studies mostly place forgiveness on a continuum of victim versus perpetrator, forgiveness versus unforgiveness. From the offenders' shared stories it became clear how forgiveness operates on a relational continuum, most relevant in this incarcerated space. Furthermore, the steps and parties involved in this forgiveness cycle are independent of one another. Regarding independency, most participants voiced that finding meaning in suffering does not depend on forgiveness from others, nor in establishing any victim-transgressor relationship. The offender takes an active role in this process, opposed to the passive role studies portray.

Interdependency, within a religious paradigm, in seeking forgiveness from God, one is expected to forgive others first. Some men, however, expressed that this is not a prerequisite because they believe God will grant unconditional forgiveness during their pursuit.

\section{Forgiveness is a complex relationship with God}

Some participants voiced strong emotions of anger towards God for allowing bad things to happen and causing their suffering. These expressions displayed an honesty and vulnerability that transpired in a deeper dual relationship between researchers and participant. This resulted in a significant shift in understanding how these men construct forgiveness. It emphasises the complicated relationship 
with God, however, not affecting their continuous spiritual journey. The narratives shared further highlight this interactional relationship, where God's forgiveness for their wrongful acts is not the only focus in their quest. A significant finding, in the context of their incarcerated lives, is their interdependence towards the divinity, which resembles a binary engagement of not just begging forgiveness from him, but where he acknowledges the turmoil they experience. Offenders voiced that whilst harbouring anger towards God for allowing their suffering, they can still find solace in his forgiveness.

This interactional relationship characterised by various emotions is evident of a troubled pilgrimage of approaching God, and again moving away. A significant aspect expressed in this regard is the role of self-forgiveness and the impact on how they find meaning in life whilst incarcerated. As shared by participants we concluded that self-forgiveness is most significant in a person's journey towards healing. The participating offenders explained that, to move forward it is important to accept responsibility for one's transgressions, not by condemning oneself, but by positive acts towards selfforgiveness.

Following an interactive approach, participants could articulate their experiences and feelings and displayed ownership of their forgiveness narrative. It is believed that this process enabled them to make sense of their incarcerated lives. During our engagement with the offenders, as researchers we were also faced with aspects that challenged our preconceived understanding of forgiveness and contributed to our own sense-making process.

\section{Acknowledgements}

The process of applying for ethical clearance from the Department of Correctional Services was driven by Mbongiseni Mdakane, who originally conceptualised the project.

\section{Competing interests}

The authors declare that they have no financial or personal relationship(s) that may have inappropriately influenced them in writing this article.

\section{Authors' contributions}

The authors equally contributed to the writing of this article.

\section{Ethical consideration}

Ethical clearance to conduct this study was obtained from both the University of South Africa and the Department of Correctional Services.

\section{Funding information}

This research received no specific grant from any funding agency in the public, commercial or not-for-profit sectors.

\section{Data availability statement}

Data sharing is not applicable to this article as no new data were created or analysed in this study.

\section{Disclaimer}

The views and opinions expressed in this article are those of the authors and do not necessarily reflect the official policy or position of any affiliated agency of the authors.

\section{References}

Alase, A., 2017, 'The Interpretative Phenomenological Analysis (IPA): "A guide to a good qualitative research approach"', International Journal of Education \& Literacy Studies 5(2), 9-19. https://doi.org/10.7575/aiac.ijels.v.5n.2p.9

Couenhoven, J., 2010, 'Forgiveness and restoration: A theological exploration', The Journal of Religion 90(2), 148-170. https://doi.org/10.1086/649846

Edwards, D., 2010, 'God's Redeeming Act: Deifying transformation', Worldviews 14(2), 243-257.

Escher, D., 2013, 'How does religion promote forgiveness? Linking beliefs, orientations, and practices', Journal for the Scientific Study of Religion 52(1), 100-119.

Fincham, F.D. \& May, R.W., 2019, 'Self-forgiveness and well-being: Does divine forgiveness matter?', The Journal of Positive Psychology 14(6), 1-6. https://doi. forgiveness matter?', The Journal of Posit
org/10.1080/17439760.2019.1689411

Gadamer, H.G., 2004, Truth and method, 2nd edn., transl. J. Weinsheimer \& D.G. Marshall, Continuum, New York, NY.

Hall, J.H. \& Fincham, F.D., 2005, 'Self-forgiveness: The stepchild of forgiveness research', Journal of Social and Clinical Psychology 24(5), 621-637.

Inazu, J.D., 2009, 'No future without (personal) forgiveness: Re-examining the role of forgiveness in transitional justice', Human Rights Review 10(3), 309-326. https:// doi.org/10.1007/s12142-009-0120-8

Jacobson, J. \& Fair, H., 2017, Sense of self and responsibility: A review of learning from the Winston Churchill Memorial Trust Prison Reform Fellowships - Part V, Institute for Criminal Policy Research, Birkbeck, University of London, London.

Karremans, J.C., Van Lange, P.A.M. \& Holland, R.W., 2005, 'Forgiveness and its associations with prosocial thinking, feeling, and doing beyond the relationship with the offender', Personality And Social Psychology Bulletin 31(10), 1315-1326. https://doi.org/10.1177/0146167205274892

Krause, N., 2018, 'Assessing the relationships among religion, humility', Research in Human Development 1(5), 33-49.

Krause, N. \& Ellison, C., 2003, 'Forgiveness by god, forgiveness of others, and psychological', Journal for the Scientific Study of Religion 42(1), 77-94.

Kubai, A., 2016, "“Confession" and "Forgiveness" as a strategy for development in post-genocide Rwanda', HTS Teologiese Studies/Theological Studies 72(4), a3562. https://doi.org/10.4102/hts.v72i4.3562

Landman, C., Ncongwane, H.J. \& Pieterse, T., 2019, 'Men serving long-term sentences in Zonderwater correctional centre, South Africa: Religious identity and behavioura change', HTS Teologiese Studies/ Theological Studies 75(3), 1-11, viewed from https://doi.org/10.4102/hts.v75i3.5274.

Landman, C. \& Pieterse, T., 2019, '(Re)constructing God to find meaning in suffering: Men serving long-term sentences in Zonderwater', HTS Teologiese Studies/
Theological Studies 75(4), a5520. https://doi.org/10.4102/hts.v75i4.5520

Lijo, K.J., 2018, 'Forgiveness: Definitions, perspectives, contexts and correlates', Journal of Psychology \& Psychotherapy 8(3), 1-5, viewed 6 January 2020 from https://doi.org/10.4172/2161-0487.1000342.

Magezi, V. \& Magezi, C., 2017, 'Healing and coping with life within challenges of spiritual insecurity: Juxtaposed consideration of Christ's sinlessness and African ancestors in pastoral guidance', HTS Teologiese Studies / Theologial Studies 72(3), 1-12. https://doi.org/10.4102/hts.v73i3.4333

Maguire, D., 2016, 'Troubled spaces', Royal Society for the encouragement of Arts, Manufactures and Commerce Journal 162(5566), 30-33, viewed 25 February 2020 from https://www.jstor.org/stable/10.2307/26204500.

McCullough, M.E., 2001, 'Forgiveness: Who does it and How do they do it?', Current Directions in Psychological Science 10(6), 194-197.

McCullough, M.E., Kurzban, R. \& Tabak, B.A., 2010, 'Evolved mechanisms for revenge and forgiveness', in P.R. Shaver \& M. Mikulincer (eds.), In Human aggression and violence: Causes, manifestations, and consequences, pp. 221-238, American Psychological Acssociation, Washington DC.

McCullough, M.E. \& Van Oyen-Witvliet, C., 2002, 'The psychology of forgiveness', in C.R. Lopez \& S.J. Snyder (eds.), The handbook of positive psychology, pp. 446-458, Oxford University Press, New York, NY.

McCullough, M.E., Worthington, E.L. \& Rachal, K.C., 1997, 'Interpersonal forgiving in close relationships', Journal of Personality and Social Psychology 73(2), 321-336. https://doi.org/10.1037/0022-3514.73.2.321

McElroy, S., Choe, E., Westbrook, C. \& Davis, D.E., 2016, 'Relational spirituality and forgiveness of intergroup offenses', Journal of Psychology \& Theology 44(3) 190-200.

Miceli, M. \& Castelfranchi, C., 2011, 'Forgiveness: A cognitive-motivational anatomy', Journal for the Theory of Social Behaviour 41(3), 260-290. https://doi. org/10.1111/j.1468-5914.2011.00465.x 
Peterson, S.J., Van Tongeren, D., Womack, S.D., Hook, J.N., Davis, D.E. \& Griffin, B.J. 2017, 'The benefits of self-forgiveness on mental health: Evidence from correlational and experimental research', The Journal of Positive Psychology 12(2), 159-168.

Pettigrove, G., 2012, 'Forgiveness without god?', Journal of Religious Ethics, Inc. 40(3), 518-544. https://doi.org/10.1111/j.1467-9795.2012.00534.x

Pieterse, T., 2019, 'Keeping up appearances: Female correctional officers shaping their work identity in a South African Correctional Centre', Masters dissertation, University of South Africa, Pretoria.

Pietkiewicz, I. \& Smith, J.A., 2014, 'A practical guide to using Interpretative Phenomenological Analysis in qualitative research psychology', Psychological Journal 20(1), 7-147. https://doi.org/10.14691/CPPJ.20.1.7

Rowan, F., 2018, 'Forgiveness and healing', Interpretation: A Journal of Bible and Theology 72(3), 293-303.

Rye, M.S., Pargament, K.I., Ali, M.A., Beck, G.L., Dorff, E.N., Hallisey, C. et al., 2000 , 'Religious persepectives on forgiveness', in M.E. McCullough (ed.), Forgiveness: Theory, research, and practice, pp. 17-40, Guilford Press, New York.
Scheffler, E., 2015, 'Reflecting on Jesus' teaching on forgiveness from a positive psychological perspective', HTS Teologiese Studies/Theological Studies 70(1), Art. \#2982, 10 pages. https://doi.org/10.4102/hts.v70i1.2982

Scotland, J., 2012, 'Exploring the philosophical underpinnings of research: Relating ontology and epistemology to the methodology and methods of the scientific interpretive, and critical research paradigms', English Language Teaching 5(9), 9-16. https://doi.org/10.5539/elt.v5n9p9

Terre Blanche, M., Durheim, K. \& Painter, D., 2012, Research in practice, 2nd edn., University of Cape Town Press, Cape Town.

Worthington, E.L., Van Oyen Witvliet, C., Pietrini, P. \& Miller, A.J., 2007, 'Forgiveness, health, and well-being: A review of evidence for emotional versus decisional forgiveness, dispositional forgivingness, and reduced unforgiveness, Journal of Behavioral Medicine 30(4), 291-302. https://doi.org/10.1007/s10865-007-9105-8

Worthington, E.L., Rueger, S.Y., Davis, E.B. \& Wortham, J., 2019, “"Mere” Christian forgiveness: An ecumenical Christian conceptualization of forgiveness through the
lens of stress-and-coping theory', Religions 10(44), 1-15. https://doi.org/10.3390/ rel10010044 